medRxiv preprint doi: https://doi.org/10.1101/2020.11.24.20237263; this version posted November 27, 2020. The copyright holder for this preprint (which was not certified by peer review) is the author/funder, who has granted medRxiv a license to display the preprint in perpetuity. All rights reserved. No reuse allowed without permission.

\title{
1 The Unyvero Hospital-Acquired pneumonia panel for diagnosis of secondary bacterial
} 2 pneumonia in COVID-19 patients

3 Chaitanya Tellapragada ${ }^{1 *}$ and Christian G. Giske $e^{1,2}$

6 Author Affiliations:

$7{ }^{1}$ Divison of Clinical Microbiology, Department of Laboratory Medicine, Karolinska Institute,

8 Stockholm, Sweden.

$9 \quad{ }^{2}$ Division of Clinical Microbiology, Karolinska University Hospital, Stockholm, Sweden.

11 *Corresponding Author

12 Chaitanya Tellapragada

13 Postdoctoral Researcher, Divison of Clinical Microbiology

14 Department of Laboratory Medicine, Karolinska Institute

15 Alfred Nobels Allé 8

1614183 Stockholm, Sweden.

17 Email: Chaitanya.tellapragada@ki.se. 
medRxiv preprint doi: https://doi.org/10.1101/2020.11.24.20237263; this version posted November 27, 2020. The copyright holder for this preprint (which was not certified by peer review) is the author/funder, who has granted medRxiv a license to display the preprint in perpetuity.

19

20

\section{Abstract}

The study was undertaken to evaluate the performance of Unyvero Hospitalized Pneumonia Panel (HPN) Application, a multiplex PCR based method for the detection of bacterial pathogens from lower respiratory tract (LRT) samples, obtained from COVID-19 patients with suspected secondary hospital-acquired pneumonia. Residual LRT samples obtained from critically ill COVID-19 patients with predetermined microbiological culture results were tested using the Unyvero HPN Application. Performance evaluation of the HPN Application was carried out using the standard-of-care (SoC) microbiological culture findings as the reference method. Eighty-three LRT samples were used in the evaluation. The HPN Application had a full concordance with SoC findings in 59/83 (71\%) samples. The new method detected additional bacterial species in 21 (25\%) and failed at detecting a bacterial species present in lower respiratory culture in 3 (3.6\%) samples. Overall the sensitivity, specificity, positive and negative predictive values of the HPN Application were 95.1\% (95\%CI: 96.5-98.3\%); $98.3 \%$ (95\% CI: 97.5-98.9\%); $71.6 \%$ (95\% CI: $61.0-80.3 \%$ ) and 99.8\% (95\% CI: 99.3-99.9\%) respectively. In conclusion, the HPN Application demonstrated higher diagnostic yield in comparison with the culture and generated results within 5 hours.

Keywords: Hospital-Acquired pneumonia; COVID-19; Rapid-diagnostic tests; Bacterial pneumonia; multiplex-PCR. 
medRxiv preprint doi: https://doi.org/10.1101/2020.11.24.20237263; this version posted November 27, 2020. The copyright holder for this

\section{Introduction}

Lower respiratory tract infections (LRTIs) have a diverse microbial etiology including bacterial, viral and fungal pathogens. Early and accurate identification of the infectious etiology causing LRTIs is crucial for deciding the course of treatment with reference to selection of appropriate antimicrobial therapy. Pathogen-specific antimicrobial therapy among patients with more severe form of LRTIs, such as community- and ventilator-associated pneumonia has been reported to reduce the length of hospital-stay, health care costs and adverse clinical outcomes [1]. Historically, etiological diagnosis of bacterial pneumonia has primarily been based on the microbiological culture findings. Minimum turn-around time for results from the time of sample inoculation for culture and antimicrobial susceptibility testing is approximately 36-48 hours. Sensitivity of the microbiological culture techniques for recovery of bacterial pathogens from lower respiratory tract samples can be hindered by several factors including: i) prior administration of antibiotics; ii) poor quality and low quantity of the sample; iii) overgrowth of commensal respiratory tract microbiota; iv) technical expertise of the microbiologist reading the culture plates. Semi-quantitative cultures of respiratory samples often cannot distinguish colonizer from pathogen. This problem can be overcome by using quantitative culture techniques that are more conclusive but are more laborious and cumbersome to perform.

Amidst these pre-existing challenges with reference to etiological diagnosis of LRTIs, COVID-19 has rapidly emerged as a major public health concern, worldwide. Current estimates suggest that nearly $80 \%$ of the patients admitted in the ICU with COVID-19 receive antibiotics [2]. In contrast, from a recent meta-analysis that included 24 studies from various countries, it was reported that bacterial co-infections were reported in only $7-15 \%$ of the patients admitted in the ICU [3]. Antibiotic therapy in the absence of etiological diagnosis of infection has both clinical and public health implications. Inappropriate use of antibiotics is a well-established driver for emergence of antimicrobial resistance among bacterial pathogens.

80 Given this context, it is important to verify whether newer diagnostic modalities capable of detecting bacterial pathogens from native clinical specimens can be useful in providing early and accurate etiological diagnosis of pneumonia among critically ill COVID-19 patients [4].

83 Herein, we evaluated the performance of Unyvero Hospitalized Pneumonia (HPN)

84 Application (Curetis, Germany $\mathrm{GmbH}$ ), a multiplex PCR based method, in comparison with 
medRxiv preprint doi: https://doi.org/10.1101/2020.11.24.20237263; this version posted November 27, 2020. The copyright holder for this

85

86

87

88

89

90

91

92

93

94

95

96

97

98

99

100

101

102

103

104

105

106

107

108

109

110

111

112

113

114

115

116

117

118

standard-of care microbiological culture findings for detection of bacterial pathogens from lower respiratory tract (LRT) samples obtained from critically ill COVID-19 patients.

\section{Material and Methods}

Study details: A laboratory-based comparative study was undertaken at the Department of Clinical Microbiology, Karolinska University Hospital, Stockholm, Sweden from April 2020 through June 2020, during the first wave of the COVID-19 pandemic in Stockholm, Sweden. Study samples: Lower respiratory samples frozen in the biobank of Karolinska University Laboratory were used in the present study. The biobank consisted of residual LRT samples (after standard cultures) received at the clinical microbiology laboratory during March 2020 June 2020, obtained from hospitalized COVID-19 patients in Stockholm with a clinical suspicion of secondary bacterial infection. Microbiology culture reports, sample types and baseline demographic characteristics of the subjects were extracted from the laboratory information system using the laboratory identification numbers of the samples available in the biobank. Selection of the samples was carried out based on the following inclusion criteria: i) samples obtained from adult patients; ii) obtained from subjects admitted in the intensive-care unit; iii) samples that were either positive for normal respiratory microbiota or positive for one or more of the organism targets of the Unyvero HPN panel. Selected samples were tested with the Unyvero HPN Application.

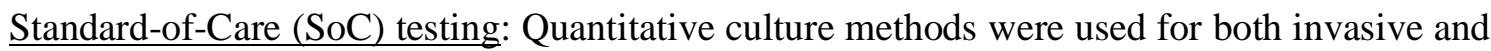
non-invasive sample types at the study laboratory. Detailed description of the sample volumes, culture media used and incubation conditions for various bacterial species are described previously [5]. Results from the cultures were reported in colony-forming units (CFU) per milliliter. Identification of the bacterial species was performed using MALDI-TOF (Bruker), as per the manufacturer's instructions. Antimicrobial susceptibility testing was performed using the disk-diffusion test and result interpretation was according to the EUCAST guidelines, version 8.0, Jan 2020 (www.eucast.org.). Detection of atypical agents such as Mycoplasma pneumoniae, Chlamydophila pneumoniae and Legionella pneumophila was performed at the study laboratory only on samples, when indicated by the clinician. For those samples, the DNA was extracted and subjected to a multiplex real-time PCR (Allplex Respiratory Panel-4, Seegene Inc.) as per the manufacturer's instructions. Testing for Pneumocystis jirovecii was not indicated by the clinicians for any of the present study samples and hence not performed. 
medRxiv preprint doi: https://doi.org/10.1101/2020.11.24.20237263; this version posted November 27, 2020. The copyright holder for this preprint (which was not certified by peer review) is the author/funder, who has granted medRxiv a license to display the preprint in perpetuity. All rights reserved. No reuse allowed without permission.

120 Testing of the study samples using Unyvero HPN Application: Frozen samples were thawed 121 for testing using the Unyvero HPN Application. Unyvero analysis was performed on the 122 Unyvero System, consisting of a Lysator, Analyzer and Cockpit, as recommended by the manufacturer (Curetis GmbH, Holzgerlingen, Germany). The Unyvero HPN Application consisted of a sample tube with lysis buffer, a sealed master mix tube and a cartridge where

125 the multiplex PCR is performed. List of the organisms and the antimicrobial resistance genes

126 available on the Unyvero HPN panel for testing are shown in Table 1. The results were 127 qualitatively reported as positive or negative for each organism/resistance marker.

Comparison of results from HPN Application results with SoC: Concordance of the HPN Application with SoC was considered when: i) same panel organism(s) detected by both HPN Application and SoC; ii) no panel organisms detected by both HPN Application and SoC; iii) no organism detected by HPN Application, culture positive for non-panel organism.

133 Discordant results were considered when: i) same sample positive for different panel 134 organisms by HPN Application and SoC; ii) culture positive for HPN panel organism, HPN 135 Application negative; iii) HPN Application positive, culture-negative for the same organism.

136 A sample was defined as both concordant and discordant if the HPN panel and SoC results 137 had the same organism plus an additional panel organism reported by either assay with were 138 positive according the HPN-panel cutoffs. Please refer to list of concordant and discordant samples in the supplementary section (Tables S3 - S5).

141 Statistical analysis: Pathogens detected by HPN were compared to SoC results to determine

142 overall clinical sensitivity, specificity, positive and negative predictive values (PPV and NPV,

143 respectively) for all pathogens combined, together with confidence intervals according to the

144 Wilson score method [6]. Sensitivity was calculated by \# true positives/(\# true positives + \# 145 false negatives); specificity was calculated by \# true negatives /(\# true negatives + \# false 146 positives); PPV was calculated by \# true positives/(\# true positives + \# false positives); NPV 147 was calculated by \# true negatives/(\# true negatives + \# false negatives).

\section{Results}

150 Sample characteristics:

151 In total, we tested 83 samples consisting of 61 (73.5\%) tracheal secretions, 11 (13.4\%) BAL, $1528(9.7 \%)$ PSB, 2 (2.4\%) bronchial secretions and 1 (1.2\%) sputum sample. The 83 samples 
medRxiv preprint doi: https://doi.org/10.1101/2020.11.24.20237263; this version posted November 27, 2020. The copyright holder for this

153 were obtained from 68 subjects (one sample from 57 unique subjects, two samples each from

1547 subjects and three samples each from 4 subjects). The multiple samples from same patient 155 were taken on different sampling days in most cases, as indicated by the ordering clinician

156 (Table S1). Seventy-four percent (50/68) of the study subjects were male and 26\% (18/68)

157 were female. Mean age of the study subjects was $58.8 \pm 11.3$ years.

158

159 Microbial etiology of the study samples determined using SoC:

160 Of the total 83 samples, one bacterial species was isolated from 40 (48\%) and two bacterial 161 species were isolated from $18(22 \%)$ samples. Normal respiratory microbiota was isolated in $16225(30 \%)$ samples. The most commonly isolated organism isolated were S. aureus (23/83; $16327.7 \%$ ) followed by E. coli and K. aerogenes in 5 (6.0\%) samples each (Table 2). When 164 compared against the list of organisms, available on the HPN panel, the present sample cohort 165 comprised of 37 (44.6\%) samples with one organism, 12 (14.5\%) samples with two organisms 166 and $34(41,0 \%)$ samples with no organisms. Eleven (13.3\%) samples were positive with 11 167 non-panel organisms (Table S2).

169 Microbial etiology of the study samples determined using HPN Application:

170 Of the 83 samples tested, one bacterial species was detected from 34 (41.4\%), two bacterial 171 species among $19(23.1 \%)$ and three bacterial species were detected among $3(3.6 \%)$ samples.

172 No bacteria were detected from 27 (32.5\%) samples. The most detected species were 173 S. aureus $(31 / 83 ; 37.4 \%)$ followed by P. aeruginosa $(9 / 83 ; 10.9 \%)$ and S. marcescens $(8 / 83$; $1749.6 \%$ ) samples (Table 2).

176 Comparison of results from HPN Application with SoC testing:

177 When comparing results between HPN and SoC for individual panel analytes, sensitivity, 178 specificity, positive predictive value and negative predictive values of the HPN application in 179 comparison with SoC culture were: 95.1\% (95\%CI: 86.5-98.3\%); 98.3\% (95\%CI: 97.5180 98.9\%); 71.6\% (95\%CI: 61.0-80.3\%) and 99.8\% (95\%CI: 99.3-99.9\%), respectively (Table

181 2). In three cases (1x S. aureus, 1x Proteus spp., 1x K. pneumoniae), SoC reported a pathogen 182 concentration below the recommended reporting threshold for BAL specimens of $10^{3}$ $183 \mathrm{CFU} / \mathrm{mL}$ (10). Such cases were considered "subclinical" (i.e. reporting does no merit patient 184 treatment) and were regarded as a SoC negative result for this study. Another sample $(K$. 185 aerogenes) which was not quantitated by SoC was therefore also regarded as SoC negative. 186 Overall comparison of the results for concordance between both methods is shown below 
medRxiv preprint doi: https://doi.org/10.1101/2020.11.24.20237263; this version posted November 27, 2020. The copyright holder for this

187 (Table 3) and sample-wise comparison of the organism yield between both methods is listed 188 below (Table 4).

189 In total, the HPN Application could not detect an organism or had a discordant result in only $1903 / 83(3.6 \%)$ of the samples that were positive by culture for any of the panel organisms. 191 Those three samples were: i) tracheal secretion sample that was blood-tinged, positive for $K$. 192 aerogenes $>10^{5} \mathrm{CFU} / \mathrm{mL}$ by culture and HPN did not detect any organism; ii) tracheal 193 secretion sample positive for $K$. aerogenes $>10^{5} \mathrm{CFU} / \mathrm{mL}$ by culture and HPN detected $S$. 194 aureus; iii) BAL sample positive for S. aureus $\left(10^{4} \mathrm{CFU} / \mathrm{mL}\right)$ and $K$. oxytoca $\left(10^{4} \mathrm{CFU} / \mathrm{mL}\right)$ 195 by culture and the HPN Application detected only S. aureus. On the other hand, the HPN 196 Application concorded fully with the culture results from 59 (71.1\%) samples (Table S3) and 197 detected additional organisms among 21 (25.3\%) samples (Table S4). Of the 11 non-panel organisms found on SoC (Table S2), 55\% (6/11) were common oropharyngeal colonizing organisms that generally do not necessitate antibiotic escalation, and a further $45.5 \%(5 / 11)$ were organisms that would have been covered with empirical treatment.

\section{Discussion}

203

The need for early initiation of pathogen-specific antimicrobial therapy among patients with severe pneumonia using rapid diagnostic techniques (RDTs) was emphasized long before the current COVID-19 pandemic began. We report here the performance characteristics of the Unyvero HPN Application for the detection of bacterial species from native lower respiratory tract (LRT) samples, with predetermined microbiological culture results, obtained from critically ill COVID-19 patients. The Unyvero HPN Application detected additional bacterial species in $25.3 \%$ (21/83) samples and failed to detect a bacterial species in only $3.6 \%(3 / 83)$ samples tested in the present study. Further, the new method demonstrated excellent negative

212 predictive value $(99.8 \%)$ and generated results within 5 hours from the time of loading the 213 sample.

215 A recent study of the BioFire FilmArray Pneumonia panel concluded that the use of molecular diagnostic tools and the initiation of narrow-spectrum antibiotics are key elements

217 of COVID-19 antimicrobial stewardship guidelines in critically ill [7]. Based on the recent 218 estimates, nearly $80 \%$ of the hospitalized patients with COVID-19 are currently receiving 219 antibiotics, albeit in the absence of a microbiological confirmation of the bacterial infection in 220 large number of patients [2]. The rationale for antibiotic treatment in patients with COVID-19 221 seems to be based on the prior experience with bacterial super-infections, that were reported 
medRxiv preprint doi: https://doi.org/10.1101/2020.11.24.20237263; this version posted November 27, 2020. The copyright holder for this preprint (which was not certified by peer review) is the author/funder, who has granted medRxiv a license to display the preprint in perpetuity. All rights reserved. No reuse allowed without permission.

222 in nearly $11-35 \%$ patients with influenza viral infection [8]. Currently, it remains unclear 223 whether bacterial co-infections are common among patients with SARS-CoV-2 infection, at 224 the time of their admission to hospital; however, there is adequate evidence in the published

225

226

227

228

229

230

231

232

233

234

235

236

237

238

239

240

241

242

243

244

245

246

247

248

249

250

251

252

253

254

255

literature suggesting that bacterial super-infections are common among COVID-19 patients admitted to the intensive-care units[2,9,10]. It is most likely possible that the bacterial superinfections among COVID-19 patients admitted to critical care units are due to the longer durations of stay in the ICU and mechanical ventilation, rather than the viral infection itself, but nonetheless this requires diligent microbiological testing because the signs and symptoms can be similar and confounding. Given this context, the Unyvero HPN Application can be a potential RDT of choice, considering that the HPN panel is able to detect 20 bacterial species, one fungus and 17 antimicrobial resistance genes (Table 1), that includes the most common infectious etiology of both healthcare- and ventilator-associated pneumonia.

In general, diagnostic yields from LRT samples vary with the sample type used. Invasive samples such as BAL and PSB are considered to have a better yield of the causative etiology of respiratory infections, as compared with non-invasive samples such as sputum. Diagnostic thresholds for various LRT samples among patients with health-care acquired pneumonia (HAP) range between $\geq 10^{3} \mathrm{CFU} / \mathrm{mL}$ for PSB samples to $\geq 10^{5} \mathrm{CFU} / \mathrm{mL}$ for aspirates and sputum [11]. A very low yield of pathogens from sputum samples of hospitalized patients with severe form of COVID-19 was recently reported [12]. Invasive sampling techniques have been contraindicated among COVID-19 patients outside the intensive-care units, due to the risk of aerosol generation. In the present study, tracheal aspirate was the predominant (61, $73.5 \%$ ) sample type used. Nevertheless, we also included 19 (23\%) BAL or PSB samples among which four (one BAL and 3 PSB) samples had a bacterial species, isolated by culture at counts $\geq 10^{3} \mathrm{CFU} / \mathrm{mL}$. The Unyvero HPN Application flagged all these four samples as negative (Table 2). Considering the lower diagnostic threshold, recommended for PSB samples in comparison with other sample types (aforementioned), diagnostic efficacy of the HPN Application for PSB samples in particular, needs further evaluation.

In our study, the HPN Application detected additional bacterial species among 21/83 (25.3\%) samples tested. This finding is in concordance with previous studies that have reported a similar increase in the bacterial yield from LRT samples, using other molecular detection assays among non-COVID-19 patients [13-15]. Currently, the clinical implications of detecting additional bacterial species only by the molecular methods (in the absence of culture 
medRxiv preprint doi: https://doi.org/10.1101/2020.11.24.20237263; this version posted November 27, 2020. The copyright holder for this preprint (which was not certified by peer review) is the author/funder, who has granted medRxiv a license to display the preprint in perpetuity. All rights reserved. No reuse allowed without permission.

256 confirmation) remain unclear and most often it is speculated that the higher yield of the 257 molecular tests can be attributed to their ability to detect nonviable bacteria from a past 258 infection [15]. However, in our study we also observed that the HPN Application could detect 259 a bacterial pathogen from samples (from patients 4, 5, 9 and 11 in Table S1) that were 260 negative by culture initially, but subsequent cultures ordered on these patients during the later 261 course of their hospital stay were in fact positive for the same pathogen, indicating that the 262 HPN panel can detect potential pathogens earlier than culture, which may enable earlier 263 treatment and management of patients. Furthermore, the HPN Application demonstrated high 264 negative predictive value of $99.8 \%$, which would allow for reduction in unnecessary antibiotic 265 use and support antibiotic stewardship efforts. Given this context, perhaps prospective 266 diagnostic trials in the near future may assess the true positive predictive values of the 267 Unyvero HPN Application and other similar commercially available molecular RDTs.

269 Our study has a few limitations. Currently, we do not have the clinical data of the patients 270 from whom the present study samples were obtained. Because of this we could not determine 271 the: i) the proportion of samples that were sent to the microbiology laboratory prior the 272 administration of antibiotics; ii) the proportion of samples that were false positive by the HPN 273 Application due to the detection of bacterial DNA from a past infection. Another limitation of 274 the present study is that we could not determine the performance characteristics of the HPN 275 Application for the detection of genes conferring antimicrobial resistance, due to the fact that only few samples yielded drug resistant phenotypes by culture in this study cohort (data not shown here). Despite these limitations, our study identified that the Unyvero HPN

278 Application is a reliable and rapid diagnostic test with excellent negative predictive value for 279 detection of bacterial pathogens from lower respiratory tract samples.

281 In conclusion, rapid diagnostics such as the Unyvero HPN panel are imperative to evaluate 282 and test patients for bacterial pneumonia earlier in their hospital journey for more prompt and 283 appropriate treatment. Unyvero HPN demonstrated a higher diagnostic yield than culture; it is significantly faster, with turnaround time of $<5$ hours from sample to results compared with average of 2.5 days for culture, providing clinicians earlier data to inform antimicrobial decisions, especially in critically ill COVID-19 patients and the upcoming flu season.

\section{Declarations}


medRxiv preprint doi: https://doi.org/10.1101/2020.11.24.20237263; this version posted November 27, 2020. The copyright holder for this preprint (which was not certified by peer review) is the author/funder, who has granted medRxiv a license to display the preprint in perpetuity.

291 Ethics approval: Ethical permit was obtained from the Swedish Ethics Review Authority

292 (Ref No:2020-04999).

293

294 Funding: No funding was received for conducting this study.

295

296 Conflict of Interest: The authors declare that they have no conflict of interest.

298 Consent to participate: Not applicable.

Consent to publish: Not applicable.

301

Data Availability: All relevant data are available in the manuscript and the supplementary files.

Author Contributions: Both authors CT and CGG contributed to the study conception and design. The first draft of the manuscript was written by CT and CGG reviewed and approved the final version of the manuscript.

Acknowledgements: The authors thank Curetis, Germany $\mathrm{GmbH}$, for kindly providing the HPN cartridges for the present evaluation. Preliminary results were submitted as an abstract at the ESCMID Conference on Coronavirus Disease (ECCVID), September 2020.

\section{References}

[1] Garau J, Baquero F, Perez-Trallero E, Pérez J-L, Martin-Sanchez A, Garcia-Rey C, Martin-Herrero

J, Dal-Ré R (2008) Factors impacting on length of stay and mortality of community-acquired pneumonia. Clinical microbiology and infection 14 (4):322-329

[2] Langford BJ, So M, Raybardhan S, Leung V, Westwood D, MacFadden DR, Soucy J-PR, Daneman N (2020) Bacterial co-infection and secondary infection in patients with COVID-19: a living rapid review and meta-analysis. Clinical Microbiology and Infection

[3] Lansbury L, Lim B, Baskaran V, Lim WS (2020) Co-infections in people with COVID-19: a systematic review and meta-analysis. Journal of Infection

[4] Cox MJ, Loman N, Bogaert D, O'grady J (2020) Co-infections: potentially lethal and unexplored in COVID-19. The Lancet Microbe 1 (1):e11

[5] Kais M, Spindler C, Kalin M, Örtqvist Å, Giske CG (2006) Quantitative detection of Streptococcus pneumoniae, Haemophilus influenzae, and Moraxella catarrhalis in lower respiratory tract samples by real-time PCR. Diagnostic microbiology and infectious disease 55 (3):169-178 
medRxiv preprint doi: https://doi.org/10.1101/2020.11.24.20237263; this version posted November 27, 2020. The copyright holder for this preprint (which was not certified by peer review) is the author/funder, who has granted medRxiv a license to display the preprint in perpetuity. All rights reserved. No reuse allowed without permission.

330

331

332

333

334

335

336

337

338

339

340

341

342

343

344

345

346

347

348

349

350

351

352

353

354

355

356

357

358

359

360

361

362

363

364

365

366

367

368

369

370

371

372

373

374

375

376

[6] Wilson EBJJotASA (1927) Probable inference, the law of succession, and statistical inference. 22 (158):209-212

[7] Verroken A, Scohy A, Gérard L, Wittebole X, Collienne C, Laterre P-F (2020) Co-infections in COVID-19 critically ill and antibiotic management: a prospective cohort analysis. Critical Care 24 (1):1-3

[8] Klein EY, Monteforte B, Gupta A, Jiang W, May L, Hsieh YH, Dugas A (2016) The frequency of influenza and bacterial coinfection: a systematic review and meta-analysis. Influenza and other respiratory viruses $10(5): 394-403$

[9] Zhou F, Yu T, Du R, Fan G, Liu Y, Liu Z, Xiang J, Wang Y, Song B, Gu X (2020) Clinical course and risk factors for mortality of adult inpatients with COVID-19 in Wuhan, China: a retrospective cohort study. The lancet

[10] Contou D, Claudinon A, Pajot O, Micaëlo M, Flandre PL, Dubert M, Cally R, Logre E, Fraissé M, Mentec HJAoIC (2020) Bacterial and viral co-infections in patients with severe SARS-CoV-2 pneumonia admitted to a French ICU. 10 (1):1-9

[11] Kalil A, Metersky M, Klompas M Management of Adults With HAP/VAP• CID 2016: 63 (1 September)• e61. Clin Infect Dis 2016:63

[12] Hughes S, Troise O, Donaldson H, Mughal N, Moore LS (2020) Bacterial and fungal coinfection among hospitalized patients with COVID-19: a retrospective cohort study in a UK secondary-care setting. Clinical Microbiology and Infection 26 (10):1395-1399

[13] Webber DM, Wallace MA, Burnham C-AD, Anderson NW (2020) Evaluation of the BioFire ${ }^{\circledR}$ FilmArray ${ }^{\circledR}$ Pneumonia Panel for Detection of Viral and Bacterial Pathogens in Lower Respiratory Tract Specimens in the Setting of a Tertiary Care Academic Medical Center. Journal of Clinical Microbiology

[14] Gadsby NJ, McHugh MP, Forbes C, MacKenzie L, Hamilton SK, Griffith DM, Templeton KE (2019) Comparison of Unyvero P55 Pneumonia Cartridge, in-house PCR and culture for the identification of respiratory pathogens and antibiotic resistance in bronchoalveolar lavage fluids in the critical care setting. European Journal of Clinical Microbiology \& Infectious Diseases 38 (6):11711178

[15] Murphy CN, Fowler R, Balada-Llasat JM, Carroll A, Stone H, Akerele O, Buchan B, Windham S, Hopp A, Ronen S (2020) Multicenter Evaluation of the BioFire ${ }^{\circledR}$ FilmArray ${ }^{\circledR}$ Pneumonia/Pneumonia plus Panel for the Detection and Quantification of Agents of Lower Respiratory Tract Infection. Journal of Clinical Microbiology.

(1)

(1)

(1)

(1)


medRxiv preprint doi: https://doi.org/10.1101/2020.11.24.20237263; this version posted November 27, 2020. The copyright holder for this preprint (which was not certified by peer review) is the author/funder, who has granted medRxiv a license to display the preprint in perpetuity.

All rights reserved. No reuse allowed without permission.

388 Table 1: Unyvero HPN panel targets.

\section{Unyvero HPN Panel Microorganisms}

Acinetobacter baumannii complex

Chlamydia pneumoniae

Citrobacter freundii

Enterobacter cloacae complex

Escherichia coli

Haemophilus influenzae

Klebsiella aerogenes (E. aerogenes)

Klebsiella oxytoca

Klebsiella pneumoniae

Klebsiella variicola

Legionella pneumophila

Moraxella catarrhalis

Morganella morganii

Mycoplasma pneumoniae

Pneumocystis jirovecii

Proteus spp.

Pseudomonas aeruginosa

Serratia marcescens

Staphylococcus aureus

Stenotrophomonas maltophilia

Streptococcus pneumoniae

\section{Unyvero HPN Panel Antibiotic Resistance} Markers

\begin{tabular}{|c|c|}
\hline Carbapenems & $\begin{array}{l}\text { bla }_{\mathrm{KPC}} \\
\text { bla }_{\mathrm{IMP}} \\
\text { bla }_{\mathrm{NDM}} \\
\text { bla }_{\mathrm{OXA}-23} \\
\text { bla }_{\mathrm{OXA}-24 / 40} \\
\text { bla }_{\mathrm{OXA}-48} \\
\text { bla }_{\mathrm{OXA}-58} \\
\text { bla }_{\mathrm{VIM}}\end{array}$ \\
\hline $3^{\text {rd }}$ generation Cephalosporins & $b l a_{\mathrm{CTX}-\mathrm{M}}$ \\
\hline Fluoroquinolones & $\begin{array}{l}\text { gyrA83 } \\
\text { gyrA87 }\end{array}$ \\
\hline Macrolide/Lincosamide & ermB \\
\hline Oxacillins & $\begin{array}{l}\text { mecA } \\
\text { mecC }\end{array}$ \\
\hline Penicillins & $\begin{array}{l}b l a_{\mathrm{TEM}} \\
b l a_{\mathrm{SHV}}\end{array}$ \\
\hline Sulfonamides & sull \\
\hline
\end{tabular}


medRxiv preprint doi: https://doi.org/10.1101/2020.11.24.20237263; this version posted November 27, 2020. The copyright holder for this preprint (which was not certified by peer review) is the author/funder, who has granted medRxiv a license to display the preprint in perpetuity.

All rights reserved. No reuse allowed without permission.

395

396

397

398

399

400

401

402

403

404

405

406

Table 2: Concordance between Unyvero HPN Panel and SoC results by organism.

407

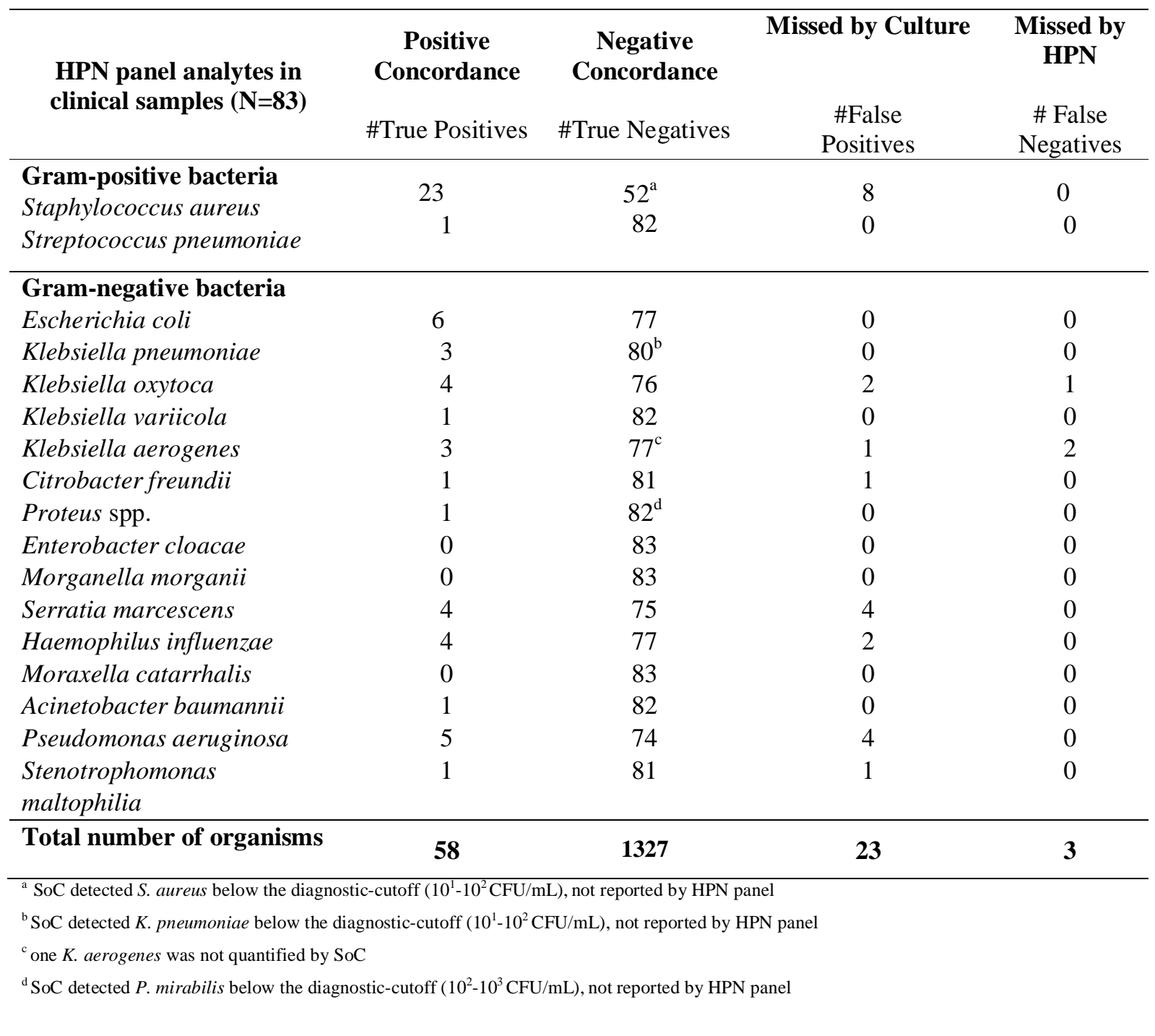


medRxiv preprint doi: https://doi.org/10.1101/2020.11.24.20237263; this version posted November 27, 2020. The copyright holder for this preprint (which was not certified by peer review) is the author/funder, who has granted medRxiv a license to display the preprint in perpetuity.

All rights reserved. No reuse allowed without permission.

423 Table 3: Concordance between HPN Application and SoC for HPN panel organism.

No of samples $(\%)$

\section{Concordant results}

$59(71.1)$

SoC positive, HPN positive

$33(39.8)$

SoC negative, HPN negative

$26(31.3)$

\section{Discordant results}

$10(12.0)$

HPN negative, SoC positive for panel organism

$1(1.2)$

SoC negative, HPN positive

HPN and SoC identifying different organisms

$1(1.2)$

\section{Both concordant and discordant}

$14(16.9)$

SoC positive, HPN (additional organism) positive

$13(15.7)$

HPN positive, SoC (additional organism) positive

$1(1.2)$

Table 4: No. (\%) of HPN panel organism isolated from each sample compared to SoC.

\begin{tabular}{ccccccc}
\hline & & None & One & $\begin{array}{c}\text { SoC } \\
\text { Two }\end{array}$ & Three & Total \\
\hline \multirow{2}{*}{ None } & $26(76.5)$ & $1(2.7)$ & 0 & 0 & 27 \\
\cline { 2 - 7 } & One & $7(20.6)$ & $26(70.3)$ & $1(8.3)$ & 0 & 34 \\
\cline { 2 - 7 } & Two & $1(2.9)$ & $10(27)$ & $8(66.6)$ & 0 & 19 \\
\cline { 2 - 7 } & & 0 & 0 & $3(25)$ & 0 & 3 \\
\hline
\end{tabular}


medRxiv preprint doi: https://doi.org/10.1101/2020.11.24.20237263; this version posted November 27, 2020. The copyright holder for this preprint (which was not certified by peer review) is the author/funder, who has granted medRxiv a license to display the preprint in perpetuity. All rights reserved. No reuse allowed without permission.

430

431

432

433

434

$\begin{array}{llllll}\text { Total } & 34 & 37 & 12 & 0 & 83\end{array}$

